\title{
Photosynthetic Product Allocations to the Organs of Pinus massoniana Are Not Affected by Differences in Synthesis or Temporal Variations in Translocation Rates
}

\author{
Xiuxiu Deng ${ }^{1,2}$, Zheng Shi ${ }^{1,3}$, Lixiong Zeng ${ }^{1,3}$, Lei Lei ${ }^{1,3}$, Xuebing Xin ${ }^{2}$, Shunxiang Pei ${ }^{2}$ and Wenfa Xiao ${ }^{1,3, *}$ \\ 1 State Forestry Administration Key Laboratory of Forest Ecology and Environment, Chinese Academy of \\ Forestry, Research Institute of Forest Ecology Environment and Protection, Beijing 100091, China; \\ dengxxiu@163.com (X.D.); shizheng@caf.ac.cn (Z.S.); zlxcaf@163.com (L.Z.); lei19860123@163.com (L.L.) \\ 2 Experimental Center of Forestry in North China, Chinese Academy of Forestry, National Permanent Scientific \\ Research Base for Warm Temperate Zone Forestry of Jiulong Mountain in Beijing, Beijing 102300, China; \\ xinxb01@163.com (X.X.); peisx@caf.ac.cn (S.P.) \\ 3 Co-Innovation Center for Sustainable Forestry in Southern China, Nanjing Forestry University, \\ Nanjing 210037, China \\ * Correspondence: xiaowenf@caf.ac.cn; Tel.: +86-10-6288-9007
}

check for updates

Citation: Deng, X.; Shi, Z.; Zeng, L.; Lei, L.; Xin, X.; Pei, S.; Xiao, W. Photosynthetic Product Allocations to the Organs of Pinus massoniana Are Not Affected by Differences in Synthesis or Temporal Variations in Translocation Rates. Forests 2021, 12, 471. https://doi.org/10.3390/ f12040471

Academic Editor: Kalliopi M. Radoglou

Received: 26 February 2021

Accepted: 9 April 2021

Published: 12 April 2021

Publisher's Note: MDPI stays neutral with regard to jurisdictional claims in published maps and institutional affiliations.

Copyright: (c) 2021 by the authors. Licensee MDPI, Basel, Switzerland. This article is an open access article distributed under the terms and conditions of the Creative Commons Attribution (CC BY) license (https:// creativecommons.org/licenses/by/ $4.0 /)$.

\begin{abstract}
Photosynthesis and the allocation of photosynthetic products are the two main factors that determine plant growth. To understand the growth and productivity of Pinus massoniana Lamb., the diurnal changes in photosynthetic rate were continuously monitored. Furthermore, the translocation and allocation of the photosynthetic products synthesized in the morning and afternoon were explored using ${ }^{13} \mathrm{C}$ pulse labeling. The results showed that: (1) on sunny days, the diurnal variation of the net photosynthetic rate showed a "double peak" curve, with an obvious "a depression" when temperatures were highest and humidity lowest. On cloudy days, it showed an irregular "jagged" curve, which was curve consistent with the variations in photosynthetically active radiation (PAR). Meanwhile, the photosynthetic rate changed with the transient changes in environmental factors such as PAR, temperature, and humidity. (2) The mean value of the net photosynthetic rate in the morning was higher than in the afternoon, and the response of the net photosynthetic rate to environmental change (PAR, temperature, humidity, and $\mathrm{CO}_{2}$ concentration) in the morning was greater than that in the afternoon. (3) The translocation of photosynthetic products synthesized in the afternoon was faster than that in the morning. Shortly after synthesis of photosynthetic products, the translocation of products synthesized in the morning tended toward upper organs (including current-year leaves and 1-year leaves), while the translocation of products synthesized in the afternoon decreased in the upper organs. However, after 15 days of ${ }^{13} \mathrm{C}$ pulse labeling, the allocation of the photosynthetic products synthesized in the morning and afternoon tended to be the same. These results indicate that the differences in the photosynthetic products synthesized and the temporal differences in the translocation rates did not affect the final allocation of the photosynthetic products in the various organs of the P. massoniana. These results improve our knowledge of the functional phases of $P$. massoniana during the diurnal cycle.
\end{abstract}

Keywords: photosynthetic rate; translocation of photosynthetic products; allocation of photosynthetic products; diurnal variation; Pinus massoniana

\section{Introduction}

Photosynthesis is the primary process by which plants use light energy to drive the synthesis of organic compounds and it is pivotal for plant growth and productivity [1]. Regardless of ontogeny, the photosynthesis rate is highly dependent on environmental factors, such as stomatal behaviors, molecular machinery of the chloroplasts, and morphology, which are sensitive to environmental variations $[2,3]$. The diurnal variations in photosynthesis generally reflect the responses of a plant to environmental factors [4,5]. While, 
there are often transient changes in environmental factors in the natural environment, but there are few studies on the responses of the photosynthetic rate to these transient changes. The diurnal variations in photosynthesis were monitored in previous investigations by fitting the measured values at intervals of $1-2 \mathrm{~h}[6,7]$, but they were unable to accurately understand the effects of the transient environmental changes on the photosynthetic rate. However, the diurnal variations of photosynthetically active radiation (PAR), temperature, humidity, and $\mathrm{CO}_{2}$ concentrations varied with weather conditions, and this could cause diurnal variations in photosynthesis. Consequently, analyzing photosynthesis in plants during different weather conditions could provide valuable information to help better evaluate carbon assimilation and plant productivity.

The photosynthetic rate was related to accumulation of photosynthetic products. A higher amounts of products in leaves inhibited photosynthesis [8]. The accumulation of photosynthetic products differed temporally since the photosynthetic products were consumed throughout both the day and night, but they were only synthesized during the day [9]. Thus, it can be inferred that there are temporal differences in the photosynthetic rates on a daily timescale, and the appreciation of these temporal differences could help identify specific periods of the day when growth could become limited by the carbon supply.

The translocation and allocation of photosynthetic products determined plant growth and whole-plant biomass allocation $[10,11]$. The translocation of photosynthetic products from source leaves was driven by the hydrostatic gradient between the source and sink [12]. The relationship of the source/sink is dynamic, changing with the diurnal variations of the environmental factors, such as lower humidity that reduces stomatal conductance and limits the photosynthetic rate in the source [13-15] and higher temperatures that increase the consumption of photosynthetic products in the sink [16-18]. Therefore, it is reasonable to assume that translocation of photosynthetic products was different at different time periods over a daily time scale. According to Hartmann et al. [19], the allocation of photosynthetic products were thought to be controlled by the interplay of $C$ sources and potentially competing sinks within the plant. The results of Kuehny and Topa [20] showed that the allocation of photosynthetic products of the loblolly pine seedlings was not subject to short-term variations in source and sink over a day. However, it is still unknown whether there would be temporal differences in the allocation of photosynthetic products for each organ in other plants.

Pinus massoniana Lamb., which is the main reserve forest species in China, is also a major afforestation tree species used in the subtropical areas of China. The diurnal variation characteristics of the photosynthetic rate [7] and the translocation and allocation characteristics of its photosynthetic products have been documented [21]. However, uncertainty still remains regarding the temporal differences in the translocation and allocation of the photosynthetic products on a daily time scale. Here, the photosynthetic rate and environmental factors of the P. massoniana were continuously monitored, and ${ }^{13} \mathrm{C}$ pulse labeling was performed in the morning and afternoon, respectively, to determine the diurnal variations of the photosynthetic rate and to compare the temporal differences in the translocation and allocation of its photosynthetic products The major objectives of this study were as follows: (1) to explore the diurnal variations of the photosynthetic rate of $P$. massoniana under different weather conditions; (2) to compare the differences in the synthesis capacity for photosynthetic products between the morning and afternoon; and (3) to explore whether there were differences in the translocation and allocation of the photosynthetic products synthesized in the morning and afternoon, respectively.

\section{Materials and Methods}

\subsection{Study Site}

Experiments were conducted at the Forest Ecosystem State Positioning Observation Station in the Three Gorges Reservoir area $\left(110^{\circ} 54^{\prime} \mathrm{E}, 30^{\circ} 53^{\prime} \mathrm{N}, 375 \mathrm{~m}\right.$ altitude), Zigui County, Hubei Province, China (Figure 1). It had a subtropical temperate continental mon- 
soon climate, with a mean annual precipitation of $1245 \mathrm{~mm}$, a mean monthly temperature of $16.5^{\circ} \mathrm{C}$, and average daily humidity of $60-80 \%$ [22]. P. massoniana is one of the main coniferous species in this area. The monthly mean temperatures and precipitations from 2016 to 2018 at the study site are shown in Figure 2.

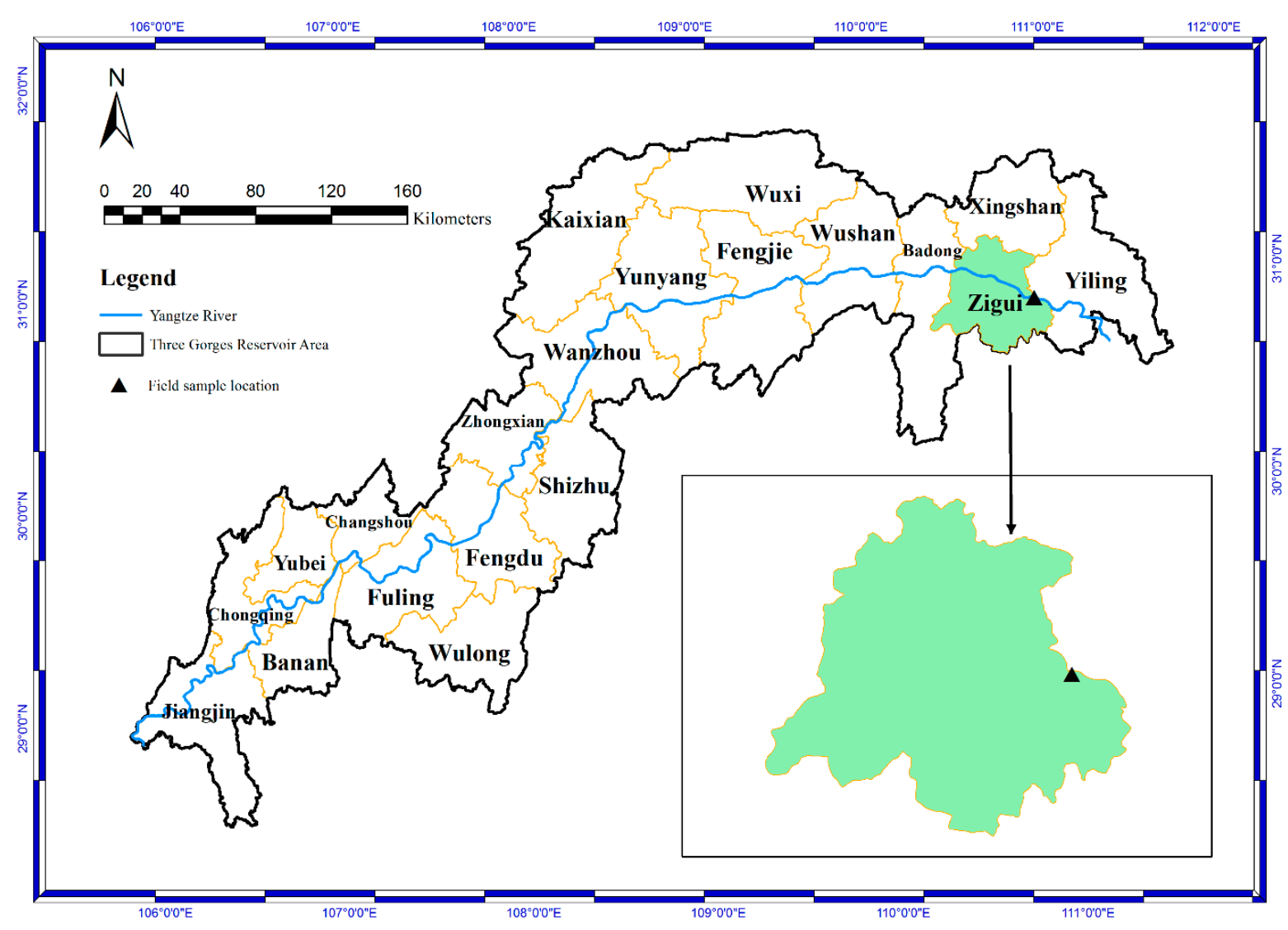

Figure 1. Diagram of the field experimental site.

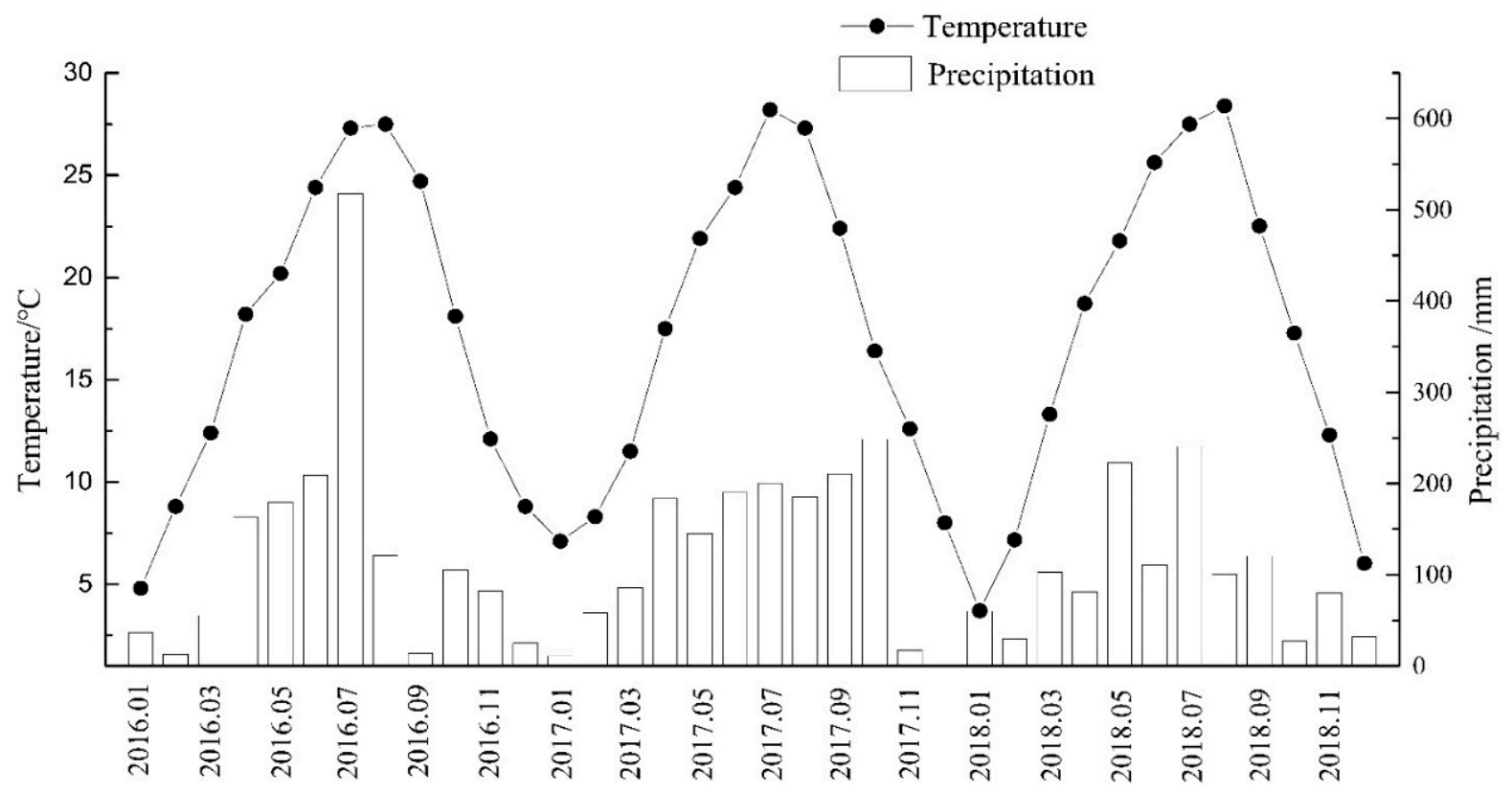

Figure 2. Monthly temperature and precipitation during 2016-2018 in Zigui County. 


\subsection{Plant Materials}

In March 2018, 100 two-year-old P. massoniana seedlings were randomly assigned to open conditions, and each was planted in a separate pot $(32 \mathrm{~cm}$ in diameter, $27 \mathrm{~cm}$ in height), and filled with $10 \mathrm{~kg}$ of soil. The soil was collected from the P. massoniana forest stands within $2 \mathrm{~km}$ of the experimental site. The basic physical and chemical properties of the experimental soil were the same as those previously described by Deng et al. [23]. On rainless day, the plants received compensatory irrigation by weighing daily at 18:00 to maintain the field capacity level. In July 2018, the mean height of the seedlings was $53.58 \mathrm{~cm}$, and the average stem diameter was $10.18 \mathrm{~mm}$.

\subsection{Diurnal Variations in Photosynthesis and Environmental Factors}

From 18 July to 7 August 2018, the diurnal variations in the photosynthetic rate were continuously measured using the multi-leaf chamber dynamic photosynthetic instrument (YZQ-100E) on the rainless days, and four P. massoniana seedlings were selected for measurement at each time point. A cluster of current year leaves were selected in each seedling and enclosed in the cuvettes. The measurement principles and methods were consistent with those previously described by Zhang et al. [24]. The net $\mathrm{CO}_{2}$ exchange was measured by the differential $\mathrm{CO}_{2}$ concentrations of the inlet and outlet, which were automatically determined every $105 \mathrm{~s}$ for one cuvette, so that each cuvette was measured every $7 \mathrm{~min}$.

Meanwhile, the photosynthetically active radiation (PAR), temperature, humidity, and $\mathrm{CO}_{2}$ concentrations were automatically recorded. After the measurements, the measured leaves were cut off, and the leaf area (LA) was measured.

The net photosynthetic rate $\left(\mathrm{Pn}, \mu \mathrm{mol} \cdot \mathrm{m}^{-2} \cdot \mathrm{s}^{-1}\right)$ was calculated as follows:

$$
\mathrm{Pn}=\mathrm{k} \times(\mathrm{C} 1-\mathrm{C} 2) \times \mathrm{F} / \mathrm{LA}
$$

where $\mathrm{k}$ is the conversion factor $\left(\mathrm{min} \cdot \mathrm{L}^{-1}\right), \mathrm{C} 1$ and $\mathrm{C} 2$ are the $\mathrm{CO}_{2}$ concentrations at the inlet and outlet of the chamber, respectively, $\mathrm{F}$ is the velocity of air $\left(\mathrm{L} \cdot \mathrm{min}^{-1}\right)$, and LA is the area of the measured leaves $\left(\mathrm{m}^{2}\right)$.

\section{4. ${ }^{13} \mathrm{C}$-Labeling Experiments}

According to the measured results, the diurnal variations for the photosynthetic rate of P. massoniana on sunny days was a "double peak" curve, with a peak in the morning and a peak in the afternoon. Therefore, the labeled plants were divided into two groups for ${ }^{13} \mathrm{CO}_{2}$ pulse labeling in the morning (8:00-11:00) and in the afternoon (14:00-17:00), respectively.

On 7 August, 2018, 30 plots of $P$. massoniana seedlings were selected and divided into two groups randomly, labeled with ${ }^{13} \mathrm{CO}_{2}$ in the morning (8:00-11:00) and afternoon (14:0017:00), respectively. The ${ }^{13} \mathrm{CO}_{2}$ pulse labeling was conducted in a homemade plexiglass chamber (length $\times$ width $\times$ height: $1.5 \mathrm{~m} \times 0.9 \mathrm{~m} \times 1.2 \mathrm{~m}$ ). To avoid gas leakage, the chamber was placed in a concave groove and sealed with water. ${ }^{13} \mathrm{CO}_{2}$ was produced by $1 \mathrm{~N}^{13} \mathrm{C}-\mathrm{Na}_{2} \mathrm{CO}_{3}$ solution and $1 \mathrm{~N} \mathrm{H}_{2} \mathrm{SO}_{4}$ solution, and the concentration of the $\mathrm{CO}_{2}$ was maintained at $400 \mathrm{ppm}$ by controlling the flow rate of the ${ }^{13} \mathrm{C}_{-}-\mathrm{Na}_{2} \mathrm{CO}_{3}$ solution. Three fans were installed inside the chamber and were used to mix the air thoroughly during the labeling.

\subsection{Sampling and Chemical Analysis}

We harvested the samples before and five times after each pulse labeling started, at $0,1,5,9$, and 15 days. At each sampling time, we took three seedlings and divided them into current year leaves, 1-year leaves, branches, stems, and roots. The samples were transferred into paper envelopes and dried to a constant mass at $65^{\circ} \mathrm{C}$, weighed, and ball milled before analysis. The $\delta^{13} \mathrm{C}$ and $\mathrm{C}$ contents were determined using an isotope ratio mass spectrometer (Delta V Advantage) coupled with an elemental analyzer (Flash 2000 EA-HT) (Thermo Fisher Scientific Inc., Waltham, MA, USA). 


\subsection{Constructing Upper Boundary Lines}

To analyze the relationships between photosynthesis and each environmental factor, the boundary line approach was adopted. The upper boundary line was the line connecting the data points at the outer margin of the environmental factors, which was supposed to be the only factor limiting photosynthesis [25]. To calculate the boundary points, each environmental factor dataset was divided into 8 or 10 equidistant segments. In each segment, the average of the photosynthetic rate value, which was at least one standard deviation greater than the mean photosynthetic rate value, was adopted as the $Y$-axis value of the upper boundary point, and the median value of each environmental factor in each segment was used as the $X$-axis value of the upper boundary point. Finally, according to the variation trends of all boundary points, the fitting was curved.

\subsection{Carbon Isotope Analysis}

All carbon isotope values were reported using the isotope delta values $\left(\delta^{13} \mathrm{C}\right)$, that is, ${ }^{13} \mathrm{C} /{ }^{12} \mathrm{C}$, were expressed in per mil (\%) in relation to the international reference standard:

$$
\delta^{13} \mathrm{C}=\left[\left(\mathrm{R}_{\text {sam }}-\mathrm{R}_{\mathrm{std}}\right) / \mathrm{R}_{\mathrm{std}}\right] \times 1000
$$

where $R_{\text {sam }}$ and $R_{\text {std }}$ are the ${ }^{13} \mathrm{C} /{ }^{12} \mathrm{C}$ ratios of the sample and standard, respectively.

The atomic percentage of ${ }^{13} \mathrm{C}$ in each organ $\left(\mathrm{F}_{i}, \%\right)$, was as follows:

$$
\mathrm{F}_{i}=\left[\left(\delta^{13} \mathrm{C}+1000\right) \times \mathrm{R}_{\mathrm{std}}\right] \times 100 /\left[\left(\delta^{13} \mathrm{C}+1000\right) \times \mathrm{R}_{\mathrm{std}}+1\right]
$$

The total amount of carbon in each organ $\left(C_{i}, \mathrm{~g}\right)$ was determined as follows:

$$
\mathrm{C}_{i}=\mathrm{T}_{i} \times \mathrm{W}_{i}
$$

where $\mathrm{W}_{i}$ is the biomass in each organ and $\mathrm{T}_{i}$ is the percentage of carbon in each organ.

The total amount of fixed ${ }^{13} \mathrm{C}$ in each organ $\left({ }^{13} \mathrm{C}_{i}, \mathrm{~g}\right)$, was determined as follows:

$$
{ }^{13} \mathrm{C}_{i}=\mathrm{C}_{i} \times\left(\mathrm{F}_{i}-\mathrm{F}_{n}\right) / 100 \times 1000
$$

where $\mathrm{F}_{n}$ is the ${ }^{13} \mathrm{C}$ atomic percentage in the unlabeled sample.

The ${ }^{13} \mathrm{C}$ allocation ratio in each organ at each sampling time $\left(\mathrm{P}_{i}, \%\right)$ was as follows:

$$
\mathrm{P}_{i}={ }^{13} \mathrm{C}_{i} /{ }^{13} \mathrm{C}_{F}
$$

where ${ }^{13} C_{F}$ is the sum of the ${ }^{13} C$ in the whole plant.

\subsection{Data Analysis}

All statistical analyses were performed using Microsoft Office Excel 2016 (Microsoft, Redmond, WA, USA) and the SPSS 18.0 software (SPSS Inc., Chicago, IL, USA). Data shown are the mean standard error (SE). Two-way-analysis-of-variance (ANOVA) was used to test the effects of the different labeling times and sampling times on the variables under evaluation. All figures were drawn using Origin 9.0 software (Origin Lab Corp., Northampton, MA, USA).

\section{Results}

\subsection{Diurnal Changes in Environmental Factors and Net Photosynthetic Rates}

As shown in Figure 3, the diurnal changes in the environmental factors (such as PAR, temperature, humidity, and air $\mathrm{CO}_{2}$ concentrations), that affect the photosynthesis of $P$. massoniana, differed under different weather conditions. On sunny days, the diurnal variations of the PAR formed a single peak curve that increased first and then decreased, and generally peaked in the middle of the day. The diurnal variations of the temperature were similar to that of PAR, but the peak time of the temperature was 1-2 $\mathrm{h}$ later than the peak time of PAR. The diurnal variations of the humidity and air $\mathrm{CO}_{2}$ concentrations were 
basically the same, and both decreased first and then increased. The trough time of the humidity was basically the same as the peak time of the temperature, and was $1-2 \mathrm{~h}$ later than the peak of the PAR. The trough time of the air $\mathrm{CO}_{2}$ concentration was the same as the peak time of the PAR. On cloudy days, the diurnal variations of the PAR formed an irregular curve. The diurnal variations in the temperature and humidity were consistent with the changes in the PAR, and showed an irregular curve. While the diurnal variations in the air $\mathrm{CO}_{2}$ concentrations were similar to those on sunny days, they decreased first and then increased. On cloudy days, the range of the diurnal variations for the PAR, temperature, humidity, and $\mathrm{CO}_{2}$ concentrations were smaller than those on sunny days.

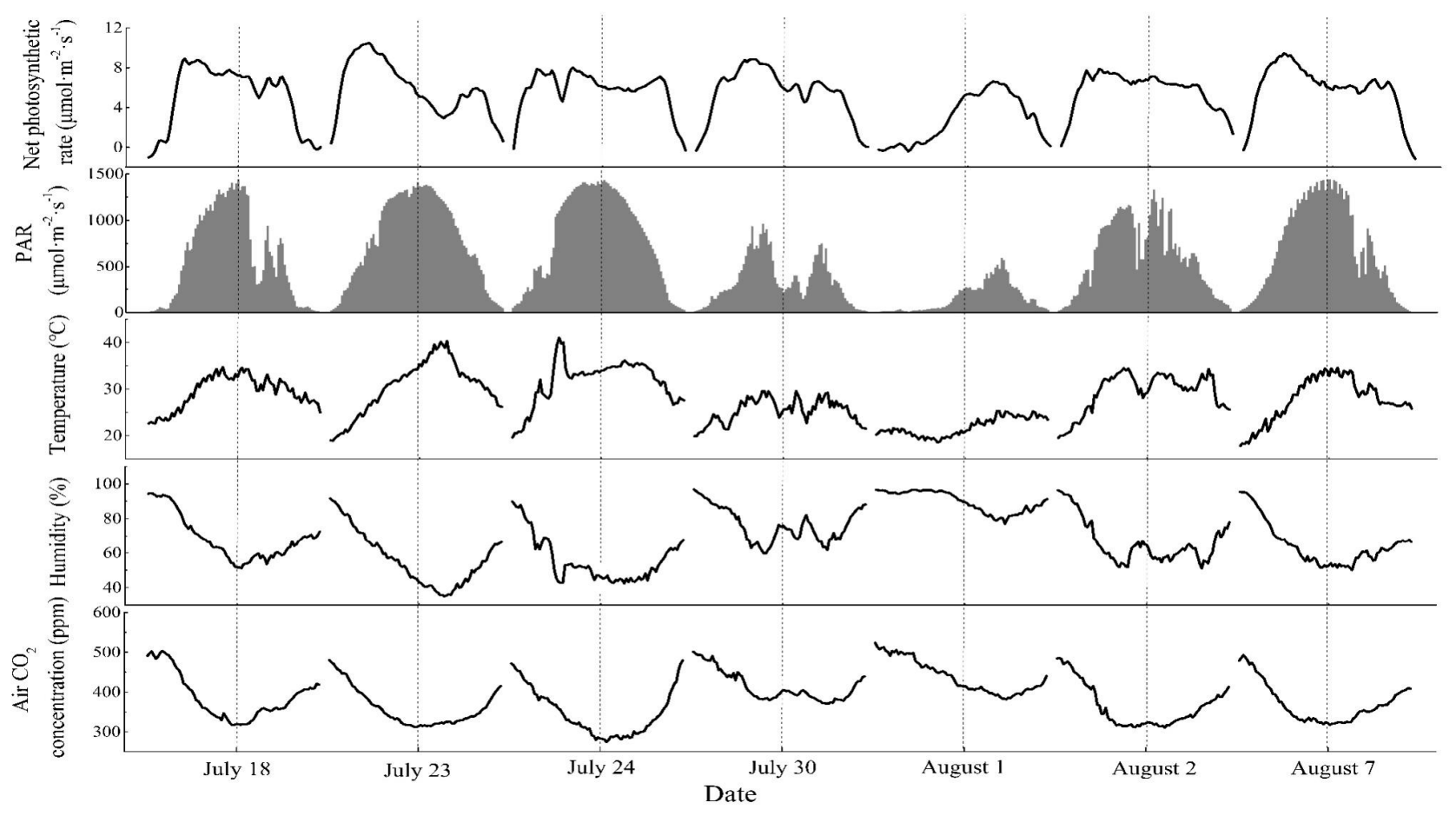

Figure 3. Diurnal variation of net photosynthetic rate and the environmental factors. Note: The dotted line represents the middle of the day. The diurnal variations of Pn was different when the weather varied (Figure 3). On sunny days (as shown on 23 July), the diurnal variations of Pn formed a "double peak" curve, with one peak in the morning (at 9:00 a.m.) and another peak in the afternoon (at 17:00 p.m.), and the peak value in the afternoon was smaller than that in the morning. The curve with an obvious "a depression," and the "trough" occurred when there were high temperatures and low humidity. Meanwhile, the Pn decreased with the temporary decrease in photosynthetically active radiation (PAR) or the temporary increase in temperature (as shown on 18 July and 24 July in Figure 3), and then gradually recovered, which resulted in a transient fluctuation of Pn diurnal variations during the day. On cloudy days (as shown on 30 July and 1 August in Figure 3), the diurnal variations of the Pn changed with the fluctuations of the PAR and showed an irregular "jagged" trend, with no "a depression".

\subsection{Differences in the Net Photosynthetic Rate at Different Time Points}

The mean value of the net photosynthetic rate at the different periods of time was calculated (as shown in Table 1). Except on 1 August, the average value of the net photosynthetic rate in the morning was greater than that in the afternoon. During the monitoring period, the average net photosynthetic rate of the P. massoniana in the morning and afternoon was 5.74 and $4.76 \mu \mathrm{mol} \cdot \mathrm{m}^{-2} \cdot \mathrm{s}^{-1}$, respectively. This indicates that the ability of P. massoniana to synthesize photosynthetic products in the morning was greater than that in the afternoon. 
Table 1. Comparison of net photosynthetic rate of P. massoniana in different periods of time.

\begin{tabular}{ccccccccc}
\hline Date & 18 July & 23 July & 24 July & 30 July & 1 August & 2 August & 7 August & Average \\
\hline $\begin{array}{c}\text { Morning } \\
\left(\mu \mathrm{mol} \cdot \mathrm{m}^{-2} \cdot \mathrm{s}^{-1}\right)\end{array}$ & 5.64 & 7.74 & 6.34 & 6.31 & 1.22 & 6.09 & 6.75 & 5.74 \\
$\begin{array}{c}\text { Afternoon } \\
\left(\mu \mathrm{mol} \cdot \mathrm{m}^{-2} \cdot \mathrm{s}^{-1}\right)\end{array}$ & 4.52 & 4.09 & 5.22 & 4.71 & 4.82 & 5.38 & 4.92 & 4.76 \\
\hline
\end{tabular}

\subsection{Short-Term Dynamics of $\delta^{13} \mathrm{C}$ in Different Organs}

After different periods of ${ }^{13} \mathrm{C}$ pulse labeling, the $\delta^{13} \mathrm{C}$ variation trend in the P. massoniana was the same (Figure 4), and both were significantly affected by the sampling time (Table 2). At $0-1 \mathrm{~d}$ after pulse labeling, the $\delta^{13} \mathrm{C}$ in the current year leaves and 1-year leaves sharply declined, and then decreased slowly until stable. At $0-1$ days after pulse labeling, the $\delta^{13} \mathrm{C}$ in the branches, stem, and roots sharply increased, and then decreased slowly until stable. The labeling time had a significant influence on the $\delta^{13} \mathrm{C}$ in the current year leaves (Table 2). As shown in Figure 5, at the end of the pulse labeling, the value of the $\delta^{13} \mathrm{C}$ in the current year leaves labeled in the morning $(1287.87 \%$ ) was greater than that labeled in the afternoon $\left(1086.03 \%\right.$ ), and the value of the $\delta^{13} \mathrm{C}$ in the other organs that were labeled in the morning was slightly greater than those labeled in the afternoon. This indicates that more photosynthates have been synthesized in the morning than in the afternoon.

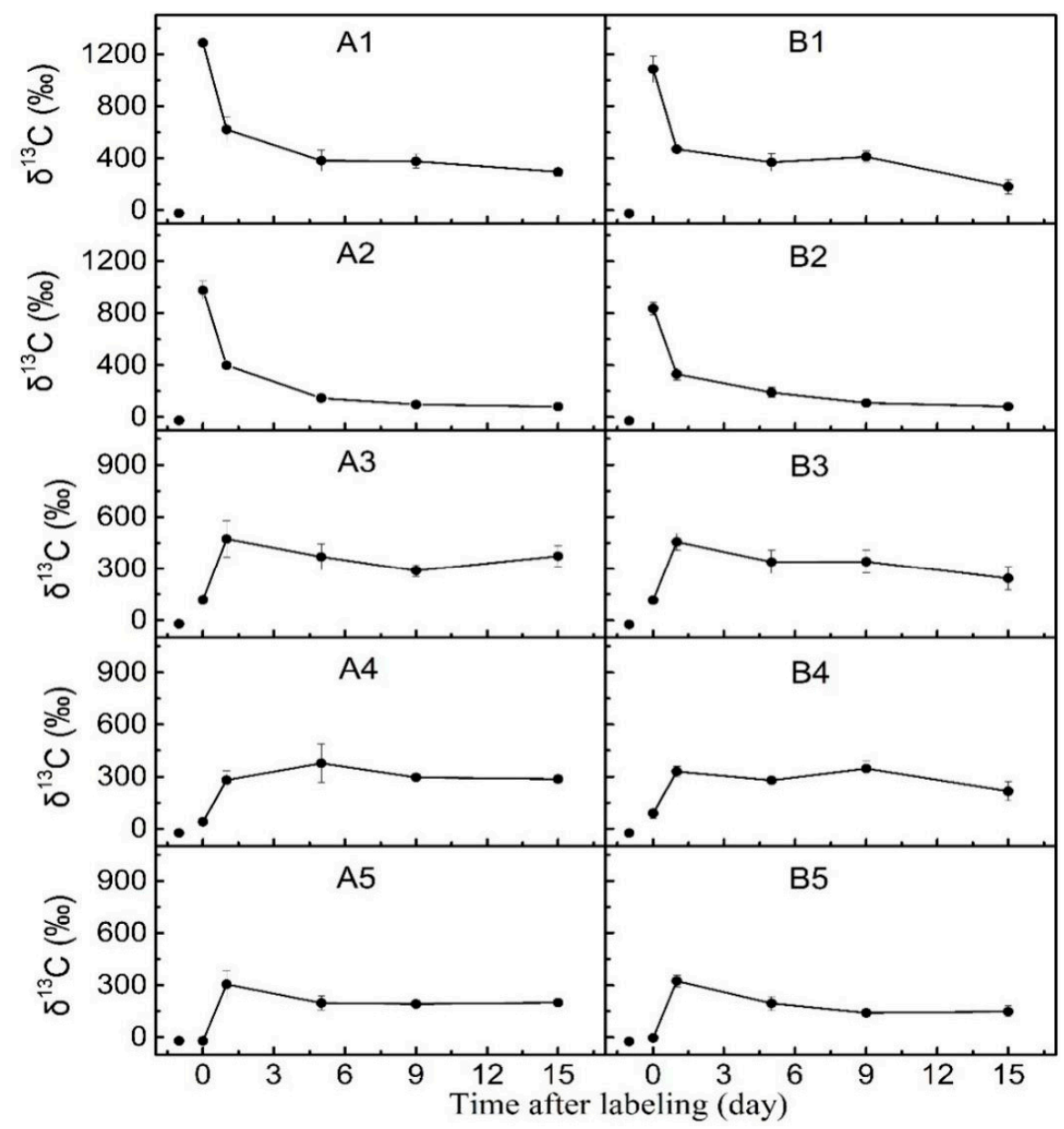

Figure 4. The change of $\delta^{13} \mathrm{C}$ in each organ of P. massoniana seedlings after different labeling periods. Note: Vertical bars illustrate standard errors of means $(n=3)$. $(\mathbf{A}, \mathbf{B})$ represent labeling in the forenoon and afternoon, respectively; 1, 2, 3, 4, and 5 represent Current-year leaves, 1-year leaves, branches, stem, and roots, respectively. 
Table 2. Variance analysis of the $\delta^{13} \mathrm{C}$ and the percentages of ${ }^{13} \mathrm{C}$ in each organ at different labeling and sampling times.

\begin{tabular}{ccccc}
\hline Indexes & Organ & Labeling Time & Sampling Time & Labeling Time $\times$ Sampling Time \\
\hline & Current year leaves & $5.005^{*}$ & $69.809^{* *}$ & 1.194 \\
\multirow{2}{*}{$\delta^{13} \mathrm{C}$} & 1-year leaves & 1.860 & $193.884^{* *}$ & 2.214 \\
& Branches & 0.400 & $8.221^{* *}$ & 0.578 \\
& Stem & 0.013 & $10.421^{* *}$ & 1.160 \\
& Roots & 0.360 & $20.819^{* *}$ & 0.455 \\
\hline \multirow{2}{*}{ Percentage of ${ }^{13} \mathrm{C}$} & Current year leaves & 2.386 & $9.274^{* *}$ & 0.376 \\
& 1-year leaves & 3.129 & $49.395^{* *}$ & 0.554 \\
& Branches & 0.715 & $6.638^{* *}$ & 0.401 \\
& Stem & 1.526 & $15.965^{* *}$ & 0.985 \\
\end{tabular}

${ }^{*} p<0.05 ;{ }^{* *} p<0.01$.

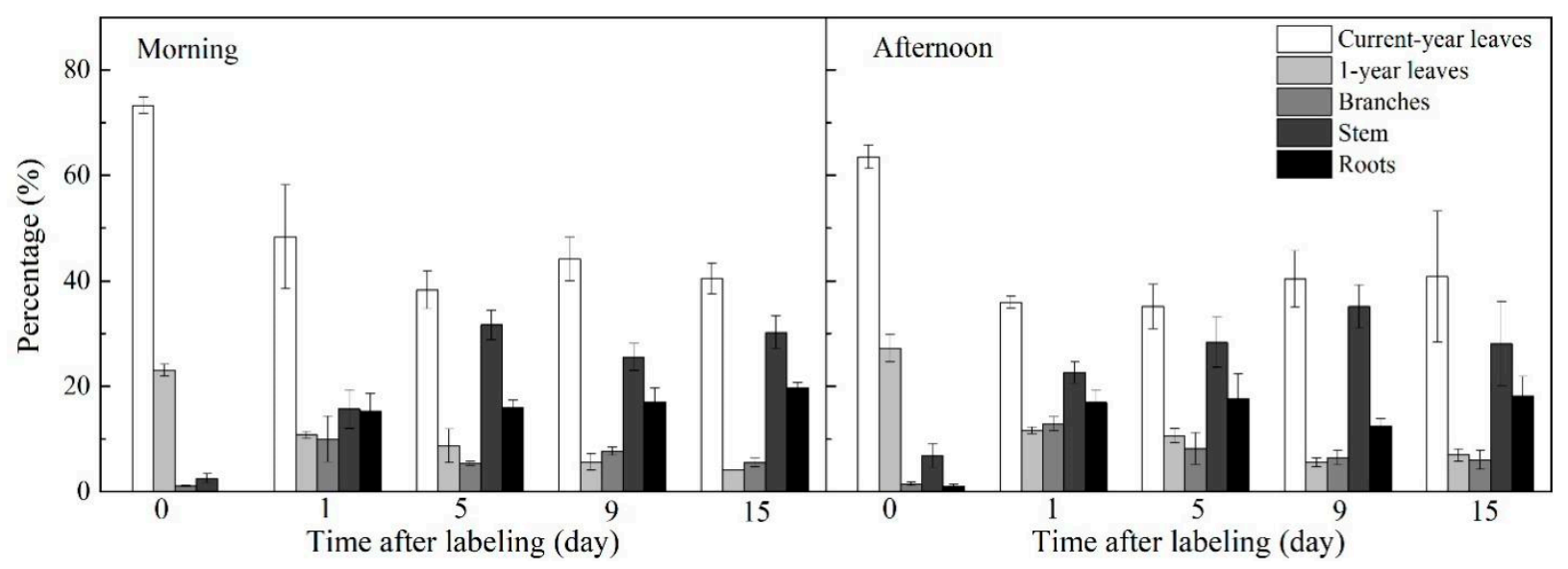

Figure 5. The percentage of ${ }^{13} \mathrm{C}$ in each organ of $P$. massoniana seedlings after different labeling periods. Note: Vertical bars illustrate standard errors of means $(n=3)$.

According to Figure 4, at the end of the pulse labeling in the morning, the $\delta^{13} \mathrm{C}$ in current year leaves, 1-year leaves, branches, stems, and roots were $1287.87 \%$, $976.26 \%$, $117.62 \%$, 39.56\% , and $-20.74 \%$, respectively. Before the pulse labeling, the $\delta^{13} \mathrm{C}$ in the corresponding organs was $-22.09 \%,-24.31 \%$, $-21.12 \%$, $-23.74 \%$, and $-21.39 \%$, respectively. The $\delta^{13} \mathrm{C}$ in the organs, other than root, was greater than that in the unlabeled plants. The results showed that the photosynthates synthesized during the pulse labeling period in the morning were not transported to the roots. At the end of the pulse labeling in the afternoon, the $\delta^{13} \mathrm{C}$ in the current year leaves, 1-year leaves, branches, stems, and roots were $1086.03 \%$, $836.43 \%$, $115.99 \%$, $88.84 \%$, and $-4.41 \%$, respectively, which were greater than those in the unlabeled plant (the $\delta^{13} \mathrm{C}$ in the corresponding organs was $23.94 \%$, $-26.95 \%$, $-23.49 \%$, $-23.61 \%$, and $-24.81 \%$, respectively). This indicated that the photosynthates synthesized during the pulse labeling period in the afternoon were transported to the roots. While according to the plant height which sampled at the end of the pulse labeled time in the morning and afternoon, they were 54.97 and $55.10 \mathrm{~cm}$, respectively, it could be inferred that the photosynthates synthesized in the afternoon had a faster transport rate than those synthesized in the morning.

\subsection{The Allocation of ${ }^{13} \mathrm{C}$ in Different Organs}

The labeling time had no significant effect on the allocation of the assimilated ${ }^{13} \mathrm{C}$ (except on current year leaves), while the sampling time significantly affected the allocation of the assimilated ${ }^{13} \mathrm{C}$ in the P. massoniana seedlings (Table 2). As shown in Figure 5, the variations in the distribution ratio of the ${ }^{13} \mathrm{C}$ in each organ fixed at different labeling times was the same. At the end of the pulse labeling in the morning and in the afternoon, the 
ratio of the ${ }^{13} \mathrm{C}$ was $73.26 \%$ and $63.48 \%$ in the current leaves, $2.57 \%$ and $6.88 \%$ in the stems, and $0.00 \%$ and $0.96 \%$ in the roots, respectively. Fifteen days after the pulse labeling, the ratio of ${ }^{13} \mathrm{C}$ in the current year leaves, 1 year leaves, branches, stems, and roots of the plants that were labeled in the morning was $40.41 \%, 4.16 \%, 5.55 \%, 30.20 \%$, and $19.68 \%$, respectively. The ratio of the ${ }^{13} \mathrm{C}$ in the corresponding organs labeled in the afternoon was $40.79 \%, 6.96 \%, 6.03 \%, 28.07 \%$, and $18.15 \%$, respectively, which was similar to those in the morning. This indicated that the allocation of the assimilated ${ }^{13} \mathrm{C}$ synthesized at different times in the plants was different at the initial stages of synthesis but unified with time.

\section{Discussion}

\subsection{Diurnal Variations of the Net Photosynthetic Rate in P. massoniana in Different Weather Conditions}

The results indicated that the diurnal variations in the Pn of the P. massoniana was closely related to the changes in the environmental conditions. The light stimulated stomatal opening at daybreak lead to an increase in Pn [26]. On sunny days, the PAR and temperatures increased, and the humidity decreased, resulting in hot-dry air, which led to stomatal conductance closure to reduce water loss [27-29]. The decrease in stomatal conductance could explain 55\% of the decrease in the photosynthetic rate [30]. Therefore, the decrease in Pn at midday was related to the decrease in stomatal conductance [15]. Under higher temperature conditions, rubisco activity decreased and respiration and photorespiration increased, which increased intercellular $\mathrm{CO}_{2}$ concentration, and reduced stomatal opening. This resulted in a depression, when temperatures were highest and humidity was lowest, caused by the decrease in stomatal conductance. On cloudy days, there were higher levels of humidity and lower temperatures (Figure 3, 30 July and 1 August). Low light was the main factor limiting the Pn of the P. massoniana. Therefore, the patterns of the diurnal changes in Pn were paralleled by those of the PAR. This was consistent with the previous results of Vongcharoen et al. [31]. In addition, the Pn of the P. massoniana decreased with the temporary increase in temperature and humidity, and gradually recovered when temperatures and humidity decreased (Figure 3, 24 July). These studies suggest that the Pn of the P. massoniana was highly sensitive to environmental changes, and exploring the Pn responses to the different weather conditions is necessary. Continuous monitoring of the diurnal variations of the Pn would provide more accurate results, especially on cloudy days.

\subsection{Temporal Differences in Photosynthetic Product Synthesis in P. massoniana}

There was a higher capacity for photosynthetic product synthesis in P. massoniana during the morning, when compared to the afternoon on sunny days (Figure 3 and Table 1). Under the same PAR conditions, the temperature in the afternoon was higher than that in the morning, and the humidity in the afternoon was lower than that in the morning (Figure 6), which resulted in a smaller stomatal conductance in the afternoon than in the morning. The stomatal conductance in the afternoon was less than that in the morning [32], which reduced the photosynthetic rate. The activity of the photosynthesis enzymes was related to the temperature [33], and the optimum activation temperature range for $\mathrm{RuBisCO}$ is $25-30{ }^{\circ} \mathrm{C}$ [34]. In our study, the temperature in the afternoon was more than $35^{\circ} \mathrm{C}$ on most days. Therefore, higher temperatures could have inactivated the Rubisco, and decreased the photosynthetic rate by non-stomatal factors [35].

According to the boundary lines of the relationships between the environmental factors and the net photosynthetic rate (Figure 7), photosynthesis in the afternoon was less affected by the environmental factors than that in the morning. This may be related to the difference in the accumulation of the photosynthetic products at the different times [36-38]. According to the literature [39-41], the higher accumulation of the photosynthetic products in the afternoon would downregulate photosynthesis. Therefore, the decreased ability to synthesize photosynthates in the afternoon when compared to the morning was not only caused by the environmental factors but also by their accumulation. 

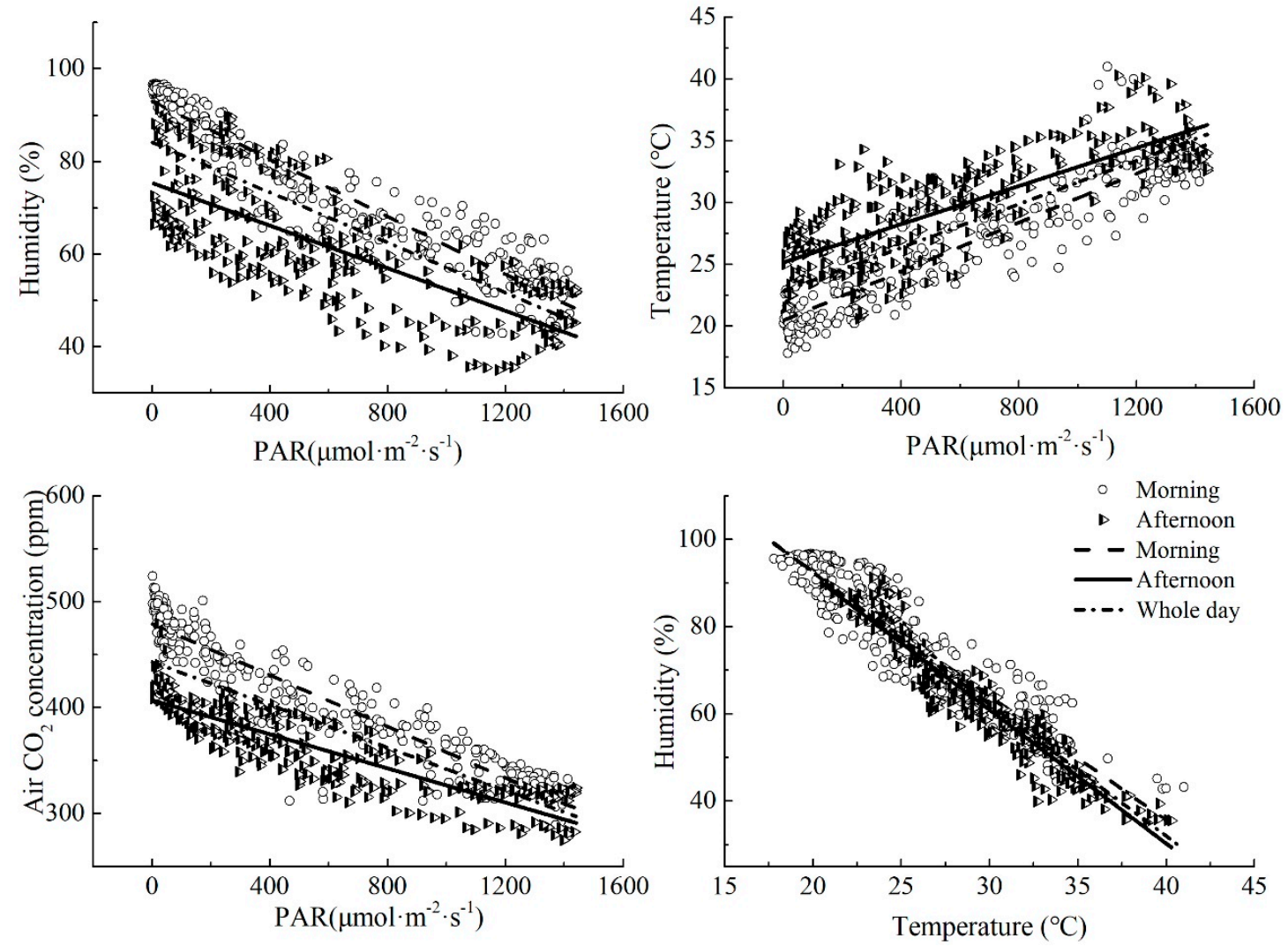

Figure 6. The relationship between each environmental factors.
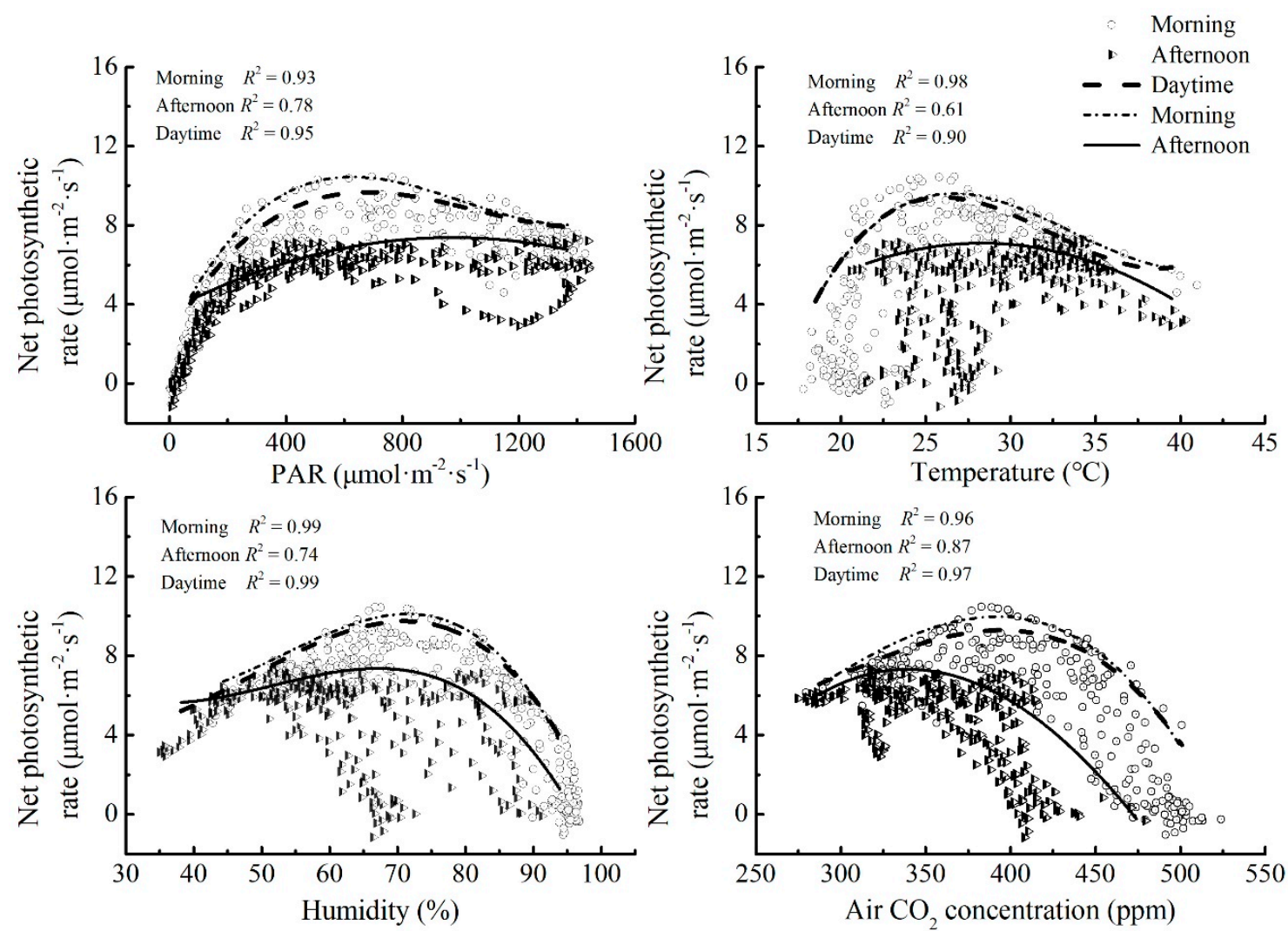

Figure 7. Responses of net photosynthetic rate to PAR, temperature, humidity, and air $\mathrm{CO}_{2}$ concentration. Note: The line was the boundary line. 


\subsection{Temporal Differences in the Translocation and Allocation of Photosynthetic Products in P. massoniana}

Our results showed a faster translocation of photosynthetic products synthesized in the afternoon compared to those synthesized in the morning. According to the literature [42,43], the long-distance transport of photosynthetic products in the phloem was driven by the differences in the photosynthetic product content between the source and the sink, while the photosynthetic product content were influenced by diurnal variations of the environmental conditions, which resulted in diurnal variations in the transport rate of the photosynthetic products [44]. First, photosynthesis continuously produced new photosynthetic products that accumulated in the upper crown [45], which resulted in higher content levels in the afternoon than in the morning, thus causing higher push pressure of the photosynthetic products from the source to the sink and a faster transport rate of the photosynthetic products. Second, during the translocation of photosynthetic products, the plant consumed part of the newly synthesized photosynthetic products through respiration [46], and the higher temperatures in the afternoon (Figures 3 and 6) would consume more of the photosynthetic products than in the morning. This resulted in a faster translocation rate of the photosynthetic products in the afternoon. A previous investigation by Dannoura et al. [47] confirmed that the translocation rate of photosynthetic products was positively correlated with temperature. In addition, a smaller stomatal opening resulted in higher rates of transport in the phloem, as this required osmotic pressure at phloem loading sites in leaves to exceed the drop in hydrostatic pressure due to transpiration [48]. The stomatal conductance in the afternoon was lower than that in the morning [49], which would also accelerate the transport of photosynthetic products in the afternoon.

At the end of the pulse labeling, the allocation of photosynthates synthesized in the morning to the leaves and branches were higher than that in the afternoon, while in the stems and roots the levels were lower than those in the afternoon. This may be due to the faster transport rate of photosynthetic products in the afternoon. Although there remain some differences in the allocation of photosynthetic products at the early stage of synthesis, the final allocation of the photosynthetic products synthesized at different times was constant. This may have been due to allocation of photosynthate products based on the storage capacity and activity of each organ [50]. So the allocation of photosynthate products synthesized at different times in each organ tended to be consistent, and this agreed with the previous results of Kuehny and Topa [20].

\section{Conclusions}

The diurnal variations in the photosynthetic rate of $P$. massoniana varied with different weather conditions, creating a "double peak" curve on sunny days, and an irregular "jagged" curve on cloudy days. This was mainly due to the different environmental factors that limited photosynthesis. On sunny days, higher temperatures and lower humidity levels were the main limiting factors, while on cloudy days, it was lower PAR. The ability to produce photosynthetic products was higher in the morning than in the afternoon, because of the environmental factors and the accumulation of photosynthates at different times of the day. Moreover, the transport rate of the photosynthates synthesized in the morning was lower than those in the afternoon, and at the initial stage of synthesizing the photosynthesis products, there were differences in their distributions, but this did not change their final allocations in each organ. Knowledge of the temporal differences in photosynthetic product synthesis, the transport rate of photosynthates, and the allocation of photosynthates could help to further elucidate the functional phases of the plant during its diurnal cycles.

Author Contributions: X.D., W.X. and Z.S. designed the experiment; X.D. and Z.S. carried out the field experiment; X.D. performed the experiments in the lab; X.D. and L.L. analyzed data and drafted the manuscript; W.X., Z.S. and X.X. revised and improved the manuscript; L.Z. and S.P. contributed to refining the ideas and discussing the results. All authors have read and agreed to the published version of the manuscript. 
Funding: This research was financially supported by the National Key Research and Development Program of the Ministry of Science and Technology of China (No. 2016YFD0600201).

Institutional Review Board Statement: Ethical review and approval were waived for this study, due to no medical research was conducted. Furthermore, it is not common for expert interviews to apply for an ethical review.

Informed Consent Statement: Informed consent was obtained from all subjects involved in the study.

Data Availability Statement: The data presented in this study are available on request from the corresponding authors. The data are not publicly available due to privacy.

Conflicts of Interest: The authors declare no conflict of interest.

\section{References}

1. Goldschmidt, E.E. Carbohydrate supply as a critical factor for citrus fruit development and productivity. HortScience. 1999, 34, 1020-1024. [CrossRef]

2. Volkova, L.; Bennett, L.T.; Tausz, M. Diurnal and seasonal variations in photosynthetic and morphological traits of the tree ferns Dicksonia antarctica (Dicksoniaceae) and Cyathea australis (Cyatheaceae) in wet sclerophyll forests of Australia. Environ. Exp. Bot. 2011, 70, 11-19. [CrossRef]

3. Turyagyenda, L.; Kizito, E.B.; Ferguson, M.; Baguma, Y.; Agaba, M.; Harvey, J.J.W.; Osiru, D.S.O. Physiological and molecular characterization of drought responses and identification of candidate tolerance genes in cassava. AoB Plants 2013, 5 , plt007. [CrossRef] [PubMed]

4. Geiger, D.R.; Servaites, J.C. Diurnal regulation of photosynthetic carbon metabolism in C3 plants. Annu. Rev. Plant Phys. 1994, 45, 235-256. [CrossRef]

5. Ding, L.; Wang, K.; Jiang, G.; Li, Y. Diurnal variation of gas exchange, chlorophyll fluorescence, and xanthophyll cycle components of maize hybrids released in different years. Photosynthetica 2006, 44, 26-31. [CrossRef]

6. Mohotti, A.J.; Lawlor, D.W. Diurnal variation of photosynthesis and photoinhibition in tea: Effects of irradiance and nitrogen supply during growth in the field. J. Exp. Bot. 2002, 367, 313-322. [CrossRef]

7. Guan, M.; Jin, Z.X.; Li, Y.L.; Wang, Q. Photo-ecological characteristics of the dominant plant species in the secondary forest surrounding Qiandao Lake, Zhejiang, China. Acta Ecol. Sin. 2015, 35, 2057-2066.

8. Ainsworth, E.A.; Bush, D.R. Carbohydrate export from the leaf: A highly regulated process and target to enhance photosynthesis and productivity. Plant Physiol. 2011, 155, 64-69. [CrossRef]

9. Cross, J.M.; von Korff, M.; Altmann, T.; Bartzetko, L.; Sulpice, R.; Gibon, Y.; Palacios, N.; Stitt, M. Variation of enzyme activities and metabolite levels in 24 Arabidopsis accessions growing in carbon-limited conditions. Plant Physiol. 2006, 142, 1574-1588. [CrossRef]

10. Ho, L.C. Metabolism and Compartmentation of Imported Sugars in Sink Organs in Relation to Sink Strength. Annu. Rev. Plant Physiol. Plant Mol. Biol. 1988, 39, 355-378. [CrossRef]

11. Geiger, D.R.; Koch, K.E.; Shieh, W.J. Effect of environmental factors on whole plant assimilate partitioning and associated gene expression. J. Exp. Bot. 1996, 47, 1229-1238. [CrossRef] [PubMed]

12. Münch, E. Die Stoffbewegung in der Pflanze; Fischer: Jena, Germany, 1930.

13. Chaves, M.M.; Pereira, J.S.; Maroco, J.; Rodrigues, M.L.; Ricardo, C.P.P.; Osório, M.L.; Carvalho, I.; Faria, T.; Pinheiro, C. How plants cope with water stress in the field. Photosynthesis and growth. Ann. Bot. 2002, 89, 907-916. [CrossRef]

14. Flexas, J.; Bota, J.; Galmés, J.; Medrano, H.; Ribas-Carbó, M. Keeping a positive carbon balance under adverse conditions: Responses of photosynthesis and respiration to water stress. Physiol. Plant. 2006, 127, 343-352. [CrossRef]

15. Raschke, K.; Reseman, A. The midday depression of $\mathrm{CO}_{2}$ assimilation in leaves of Arbutus unedo L.: Diurnal changes in photosynthetic capacity related to changes in temperature and humidity. Planta 1986, 168, 546-558. [CrossRef] [PubMed]

16. Minchin, P.E.H.; Thorpe, M.R. Apoplastic phloem unloading in the stem of bean. J. Exp. Bot. 1984, 35, 538-550. [CrossRef]

17. Etzold, S.; Zweifel, R.; Ruehr, N.K.; Eugster, W.; Buchmann, N. Long-term stem $\mathrm{CO}_{2}$, concentration measurements in Norway spruce in relation to biotic and abiotic factors. New Phytol. 2013, 197, 1173-1184. [CrossRef]

18. Blessing, C.H.; Werner, R.A.; Siegwolf, R.T.W.; Buchmann, N. Allocation dynamics of recently fixed carbon in beech saplings in response to increased temperatures and drought. Tree Physiol. 2015, 35, 585-598. [CrossRef] [PubMed]

19. Hartmann, H.; Adams, H.D.; Hammond, W.M.; Hoch, G.; Landhäusserd, S.M.; Wiley, E.; Zaehleae, S. Identifying differences in carbohydrate dynamics of seedlings and mature trees to improve carbon allocation in models for trees and forests. Environ. Exp. Bot. 2018, 152, 7-18. [CrossRef]

20. Kuehny, J.S.; Topa, M.A. Diurnal changes in allocation and partitioning of recently assimilated carbon in loblolly pine seedlings. Physiol. Plant. 1998, 104, 317-328. [CrossRef]

21. Deng, X.X.; Xiao, W.F.; Zeng, L.X.; Lei, L.; Shi, Z. Transport and distribution characteristics of photosynthates of Pinus massoniana seedlings. Sci. Silvae Sin. 2019, 55, 27-34.

22. Lei, J.P.; Xiao, W.F.; Huang, Z.L.; Zeng, L.X. Responses of Ring Width of Pinus massoniana to the Climate Change at Different Elevations in Zigui County, Three-Gorge Reservoir Area. Sci. Silvae Sin. 2009, 45, 33-39. 
23. Deng, X.X.; Xiao, W.F.; Shi, Z.; Zeng, L.X.; Lei, L. Combined Effects of Drought and Shading on Growth and Non-Structural Carbohydrates in Pinus massoniana Lamb. Seedlings. Forests 2019, 11, 18. [CrossRef]

24. Zhang, Z.; He, D.; Niu, G.; Gao, R.F. Concomitant CAM and C3 photosynthetic pathways in dendrobium officinale plants. J. Am. Soc. Hortic. Sci. 2014, 139, 290-298. [CrossRef]

25. Schmidt, U.; Thöni, H.; Kaupenjohann, M. Using a boundary line approach to analyze $\mathrm{N}_{2} \mathrm{O}$ flux data from agricultural soils. Nutr. Cycl. Agroecosyst. 2000, 57, 119-129. [CrossRef]

26. Portis, A.R.J.; Heldt, H.W. Light-dependent changes of the $\mathrm{Mg}^{2+}$ concentration in the stroma in relation to the $\mathrm{Mg}^{2+}$ dependency of $\mathrm{CO}_{2}$ fixation in intact chloroplasts. Biochim. Biophys. Acta 1976, 449, 434-436. [CrossRef]

27. Faria, T.; Silvério, D.; Breia, E.; Cabral, R.; Abadia, A.; Abadia, J.; Pereira, J.S.; Chaves, M.M. Differences in the response of carbon assimilation to summer stress (water deficits, high light and temperature) in four Mediterranean tree species. Physiol. Plant. 1998, 102, 419-428. [CrossRef]

28. De Tafur, S.M.; El-Sharkawy, M.A.; Calle, F. Photosynthesis andyield performance of cassava in seasonally dry and semiarid environments. Photosynthetica 1997, 33, 249-257. [CrossRef]

29. El-Sharkawy, M.A. Stress tolerant cassava: The role of integrative eco-physiology breeding research in crop improvement. Open J. Soil Sci. 2012, 2, 162-186. [CrossRef]

30. Yan, W.; Zhong, Y.; Shangguan, Z. A meta-analysis of leaf gas exchange and water status responses to drought. Sci. Rep. 2016, 6, 20917. [CrossRef] [PubMed]

31. Vongcharoen, K.; Santanoo, S.; Banterng, P.; Jogloy, S.; Theerakulpisut, P. Diurnal and seasonal variations in the photosynthetic performance and chlorophyll fluorescence of cassava 'Rayong 9' under irrigated and rainfed conditions. Photosynthetica 2018, 57, 268-285. [CrossRef]

32. Ribeiro, R.V.; Machado, E.C.; Santos, M.G.; Oliveira, R.F. Seasonal and diurnal changes in photosynthetic limitation of young sweet orange trees. Environ. Exp. Bot. 2009, 66, 203-211. [CrossRef]

33. Law, R.D.; Crafts-Brander, S.J. Inhibition and acclimation photosynthesis to heat stress in closely correlated with activation of ribulose-1,5-bisphosphate carboxylase/oxygenase. Plant Physiol. 1999, 120, 173-181. [CrossRef]

34. Salvucci, M.E.; Portis, A.R.J.R.; Ogren, W.L. Light and $\mathrm{CO}_{2}$ response of ribulose-1,5-bisphosphate carboxylase/oxygenase activation in arabidopsisleaves. Plant Physiol. 1986, 80, 655-659. [CrossRef]

35. Gesch, R.W.; Boote, K.J.; Vu, J.C.V.; Allen, L.H.; Bowes, G. Changes in Growth $\mathrm{CO}_{2}$ Result in rapid adjustments of ribulose-1,5bisphosphate carboxylase/oxygenase small subunit gene expression in expanding and mature leaves of rice. Plant Physiol. 1998, 118, 521-529. [CrossRef]

36. Azcon-Bieto, J. Inhibition of photosynthesis by carbohydrates in wheat leaves. Plant Physiol. 1983, 73, 681-686. [CrossRef]

37. Plaut, Z.; Mayoral, M.L.; Reinhold, L. Effects of altered sink-source ratio on photosynthetic metabolism of source leaves. Plant Physiol. 1987, 85, 786-791. [CrossRef] [PubMed]

38. Krapp, A.; Hofmann, B.; Schafer, C.; Stitt, M. Regulation of the expression of rbcS and other photosynthetic genes by carbohydrates: A mechanism of the sink regulation of photosynthesis. Plant J. 1993, 3, 817-828. [CrossRef]

39. Farnham, M.W.; Gross, H.D.; Cappy, J.J. Distribution and diurnal variation of nonstructural carbohydrate in peanut grown under unshaded and shaded conditions. Peanut Sci. 1986, 13, 51-57. [CrossRef]

40. Chaumont, M.; Morot-Gaudry, J.F.; Foyer, C.H. Seasonal and diurnal changes in photosynthesis and carbon partitioning in Vitis vinifera leaves in vines withand without fruit. J. Exp. Bot. 1994, 45, 1235-1243. [CrossRef]

41. Baber, O.; Slot, M.; Celis, G.; Kitajima, K. Diel patterns of leaf carbohydrate concentrations differ between seedlings and mature trees of two sympatric oak species. Botany 2014, 92, 535-540. [CrossRef]

42. Giaquinta, R. Sucrose hydrolysis in relation to phloem translocation in Beta vulgaris. Plant Physiol. 1977, 60, 339-343. [CrossRef] [PubMed]

43. Fisher, D.B.; Gifford, R.M. Accumulation and conversion of sugars by developing wheat grains: VI. Gradients along the transport pathway from the peduncle to the endosperm cavity during grain filling. Plant Physiol. 1986, 82, 1024-1030. [CrossRef] [PubMed]

44. Nikinmaa, E.; Sievänen, R.; Hölttä, T. Dynamics of leaf gas exchange, xylem and phloem transport, water potential and carbohydrate concentration in a realistic 3-D model tree crown. Ann. Bot. 2014, 114, 653-666. [CrossRef] [PubMed]

45. Morin, C.; Bélanger, G.; Tremblay, G.F.; Bertrand, A.; Castonguay, Y.; Drapeau, R.; Michaud, R.; Berthiaume, R.; Allard, G. Short Communication: Diurnal variations of nonstructural carbohydrates and nutritive value in timothy. Can. J. Plant Sci. 2012, 92, 883-887. [CrossRef]

46. Mildner, M.; Bader, K.F.; Leuzinger, S.; Siegwolf, R.T.W.; Körner, C. Long-term ${ }^{13} \mathrm{C}$ labeling provides evidence for temporal and spatial carbon allocation patterns in mature Picea abies. Oecologia 2014, 175, 747-762. [CrossRef]

47. Dannoura, M.; Maillard, P.; Fresneau, C.; Plain, C.; Berveiller, D.; Gerant, D.; Chipeaux, C.; Bosc, A.; Ngao, J.; Damesin, C. In situ assessment of the velocity of carbon transfer by tracing ${ }^{13} \mathrm{C}$ in trunk $\mathrm{CO}_{2}$ efflux after pulse labelling: Variations among tree species and seasons. New Phytol. 2011, 190, 181-192. [CrossRef] [PubMed]

48. Nikinmaa, E.; Hölttä, T.; Hari, P.; Kolari, P.; Mäkelä, A.; Sevanto, S.; Vesala, T. Assimilate transport in phloem sets conditions for leaf gas exchange. Plant Cell Environ. 2013, 36, 655-669. [CrossRef]

49. Sun, A.A.; Zhi, Y.B.; Jiang, P.P.; Lü, K.; Zhang, D.J.; Li, H.L.; Zhang, H.L.; Wang, Y.F.; Hua, Y.P.; Hong, G.; et al. Characteristics of and differences in photosynthesis in four desert plants in western ordos. Acta Ecol. Sin. 2019, 39, 4944-4952.

50. Taiz, L.; Zeiger, E. Plant Physiology; Song, C.P., Wang, X.L., Zhou, Y., Translators; Science Press: Beijing, China, 2015; pp. 179-234. 